\title{
Lymphocyte and macrophage subpopulations in pelvic ileal pouches
}

\author{
H J de Silva, M Jones, C Prince, M Kettlewell, N J Mortensen, D P Jewell
}

\begin{abstract}
This study aimed to characterise the mucosal cellular infiltrate in ileal reservoirs with and without pouchitis (reservoir ileitis). Intraepithelial lymphocyte counts were performed in biopsy specimens obtained from ileal pouches and compared with counts in normal ileum and normal colon. $T$ lymphocyte and macrophage subpopulations were characterised immunohistochemically in pouch biopsy specimens using a panel of monoclonal antibodies. Normal ileum was used as a control. Intraepithelial lymphocyte densities (expressed as intraepithelial lymphocyte/100 epithelial cells) in pouches with and without pouchitis were significantly less than in normal ileum, and approached counts found in normal colon. There was no significant increase in counts even in pouchitis. There were no significant differences in the helper/inducer to suppressor/cytotoxic $T$ cell (CD4:CD8) ratios between normal ileum and pouches with or without pouchitis, either in the epithelium or in the lamina propria. The proportions of RFD9+ (epithelioid cells and tingible body macrophages) and 3G8+ (CD16) macrophages were significantly higher in pouchitis compared with pouches without pouchitis or normal ileum. There were no significant differences between the three groups in the proportions of cells positive for the other macrophage markers (CD68, RFD1-dendritic cells, and RFD7-mature macrophages). The significance of low intraepithelial lymphocyte counts in ileal pouches is unknown, but this may be an adaptive response to the new luminal environment. Since an increase in RFD9+ macrophages occurs in inflammatory bowel disease, but does not occur as a non-specific response to an acute infective process, their presence in pouchitis suggests that effector mechanisms similar to those triggering the original ulcerative colitis may be operating in pouchitis.
\end{abstract}

Pouchitis (reservoir ileitis) is a major longterm complication after restorative proctocolectomy with an ileal reservoir. Unequivocal pouchitis, diagnosed using clinical, endoscopic, and histological criteria, seems to be specific to patients with previous ulcerative colitis and rarely, if ever, occurs in those who have had the operation for familial adenomatous polyposis. ${ }^{1-8}$ This suggests a close relation between ulcerative colitis and pouchitis and implies that immunological mechanisms may play an important role in the pathogenesis of pouchitis. ${ }^{489-12}$ However, in pouchitis, unlike ulcerative colitis, no controlled studies on the characterisation and quantitation of the mucosal inflammatory cell infiltrate have yet been performed.

Cell populations of the mucosa change as the bowel becomes inflamed. In active ulcerative colitis, there is a considerable inflammatory infiltrate within the lamina propria, with increased numbers of $T$ and $B$ lymphocytes and macrophages. However, there is no increase in the intraepithelial lymphocyte density when compared with normal colon. ${ }^{131+}$ The lymphocytic infiltrate within the lamina propria in ulcerative colitis contains a disproportionately high number of immunoglobulin G (IgG) containing cells, ${ }^{1516}$ primarily of the IgGl subclass. ${ }^{17}{ }^{18}$ Changes in $\mathrm{T}$ lymphocyte subsets are more difficult to interpret, and in tissue sections from patients with ulcerative colitis the ratio of $T$ cells with the helper/inducer phenotype (CD4 positive) to suppressor/cytotoxic phenotype (CD8 positive) remains similar to that found in the normal colon. ${ }^{1319}$ When compared with normal intestine, however, a greater macrophage heterogeneity has been observed in active inflammatory bowel disease. ${ }^{20-22}$ In particular, there is an increase in RFD9 positive macrophages (epithelioid cells and tingible body macrophages)..$^{21}$ Macrophages have important effector roles in inflamed gut mucosa. In active inflammatory bowel disease, intestinal macrophages are activated, as shown by increased expression of interleukin 2 receptors on their surface $^{23}$ and their increased ability to undergo respiratory burst activity ${ }^{24}$ and produce increased amounts of interleukin $1-\beta .{ }^{25}$ They also seem to have increased phagocytic activity ${ }^{26}$ and an increased ability to present antigens to $\mathrm{T}$ cells $^{27}$ and to stimulate immunoglobulin production by intestinal B cells. ${ }^{28}$

The distribution of ' $T$ lymphocyte and macrophage subsets in ileal pouch mucosa is unknown. The aims of this study were twofold - firstly to quantify intraepithelial lymphocyte densities and secondly to characterise $\mathrm{T}$ lymphocyte and macrophage subpopulations in pelvic ileal pouches with and without pouchitis.

\section{Patients and tissues}

INTRAEPITHELIAL LYMPHOCYTE DENSITY COUNTS Mucosal biopsy specimens were obtained from pelvic ileal pouches of 26 patients (18 men, median age 29.5 years (range 18-56)) at least 10 $\mathrm{cm}$ from the anal verge. Twenty three of them originally had ulcerative colitis and three had familial adenomatous polypsis. Eight (all with previous ulcerative colitis) had pouchitis defined as the occurrence of diarrhoea with pouch inflammation seen on sigmoidoscopy ${ }^{2811}$ 
TABLE I Monoclonal antibodies

\begin{tabular}{|c|c|c|}
\hline Antibody & Cells labelled & Source \\
\hline $\begin{array}{l}\text { T3-10(IgG1) (Dako) } \\
\text { X107/B2 } \\
\text { Y2/131 (IgG1) } \\
\text { EBM11 (IgG1 })^{36}\end{array}$ & $\begin{array}{l}\text { CD4 (helper/inducer T cells, some macrophages) } \\
\text { CD8 (suppressor/cytotoxic T cells) } \\
\text { CD68 (pan macrophage) } \\
\text { CD68 }\end{array}$ & $\begin{array}{l}\text { Dr D Mason (John } \\
\text { Radcliffe Hospital, } \\
\text { Oxford) } \\
\text { Dr J Morton (JRH, } \\
\text { Oxford) }\end{array}$ \\
\hline $\begin{array}{l}\text { RFD1 (IgG) })^{373 \times} \\
\text { RFD7 (IgG) })^{373 \times} \\
\text { RFD9 (IgG) })^{21223 \times 34} \\
\text { 3G8 (IgG) })^{40-13}\end{array}$ & $\begin{array}{l}\text { Dendritic cells (and some B cells) } \\
\text { Mature macrophages } \\
\text { Epithelioid cells and tingible body macrophages } \\
\text { CD16 (low affinity Fcy receptor on polymorphs } \\
\text { natural killer cells and some macrophages) }\end{array}$ & $\begin{array}{l}\text { Dr L Poulter (Royal } \\
\text { Free Hospital, } \\
\text { London } \\
\text { Dr S Gordon (Dunn } \\
\text { School of Pathology, } \\
\text { Oxford) }\end{array}$ \\
\hline
\end{tabular}

in the absence of specific pathogens in the pouch stool at the time of biopsy. The pouches had been functioning for a median of 27 months (range 8-68) and none of the patients were on any medication, apart from occasional antidiarrhoeal agents. Control tissues were (a) normal ileal mucosa $(n=12$, eight men, median age 58 years (range 35-76)) obtained at colonoscopy or from surgically resected specimens (at least $5 \mathrm{~cm}$ distant to tumour), and (b) normal large bowel mucosa $(n=12$, seven men, median age 27 years (range 22-43)) obtained at endoscopy from patients with the irritable bowel syndrome (all histologically normal). The biopsy specimens were fixed in formalin and embedded in paraffin.

\section{T LYMPHOCYTE AND MACROPHAGE \\ SUBPOPULATIONS}

Mucosal biopsy specimens were obtained from pelvic ileal pouches of 25 patients (17 men, median age 30.5 years (range 18-56)), at least 10 $\mathrm{cm}$ from the anal verge. Twenty two of the patients originally had ulcerative colitis and three had familial adenomatous polyposis. Eight (all with previous ulcerative colitis) had pouchitis, as defined previously, at the time of biopsy. The pouches had been functioning for a median of 27.5 months (range 13-68) and none of the patients were on any medication apart from occasional antidiarrhoeal drugs. Normal ileal mucosa $(n=8$, five men, median age 58 years (range 35-74)), obtained at colonoscopy or from surgical resected specimens (at least $5 \mathrm{~cm}$ distant from tumour) was used as a control. The specimens were immediately snap frozen in isopentane in liquid nitrogen and stored in liquid nitrogen until sectioning.

\section{Methods}

\section{INTRAEPITHELIAL LYMPHOCYTE COUNTS}

Sections $(4 \mu)$ of haematoxylin and eosin stained paraffin embedded tissue were used for intraepithelial lymphocyte counts. Counts were performed in the epithelium covering the entire surface of the villi, and in the case of 'flat' and colonic biopsy specimens, in the surface epithelium, where a minimum of 500 epithelial cells were counted per section, and the results were expressed as intraepithelial lymphocyte/ 100 epithelial cells. ${ }^{1329-32}$ Counts were performed under the high power $(40 \times 10)$ objective in areas of the sections where the tissue was well oriented, the plane of the section passing vertically through the epithelium and the base- ment membrane being easily identified. Counts were not performed in areas adjacent to mucosal ulceration ${ }^{13}$ and in epithelium overlying Peyer's patches.

\section{MUCOSAL MORPHOMETRY}

Mucosal morphometry was performed on the same sections used for intraepithelial lymphocyte counts. Linear measurements were made using a calibrated eye piece (Leitz) as described previously. ${ }^{33}{ }^{34}$ For each section, at least five measurements of total mucosal thickness and crypt depth were made and an index of villous atrophy (villous height/total mucosal thickness) was then calculated. ${ }^{3+35}$

\section{IMMUNOHISTOCHEMISTRY}

Serial cryostat sections of snap frozen tissue $(5 \mu)$ were stained with the panel of monoclonal antibodies using a three stage immunoperoxidase technique. Briefly, endogenous peroxidase activity was blocked with $0.3 \%$ hydrogen peroxide in Tris buffered saline (TBS) $(\mathrm{pH} \mathrm{7 \cdot 4)}$. The sections were then incubated with the respective monoclonal antibodies (undiluted supernatants) for 60 minutes (the monoclonal antibodies used are listed in Table I). After washes with TBS, they were incubated in turn for 30 minutes each with peroxidase conjugated rabbit anti-mouse immunoglobulin and peroxidase conjugated swine anti-rabbit immunoglobulin. The peroxidase reaction was developed with diaminobenzidine $(0.6 \mathrm{mg} / \mathrm{ml})$, nickel chloride $(1 \mathrm{mg} / \mathrm{ml})$, and hydrogen peroxide. One serial section from each specimen was incubated with TBS instead of the primary antibody as a negative control.

\section{CELL COUNTS}

\section{Tlymphocyte subpopulations}

Positively stained intraepithelial lymphocytes were counted as described above and expressed as intraepithelial lymphocyte/100 epithelial cells. In the lamina propria, labelled lamina propria lymphocytes were expressed as a percentage of the total number of mononuclear cells counted. ${ }^{13}$ Counts were performed in different areas of the lamina propria under the high power $(40 \times 10)$ objective using a graticule (Leitz). At least 500 mononuclear cells were counted for each section. ${ }^{13}$ Cells in and around Peyer's patches and lymphoid follicles, and mononuclear cells with elongated nuclei characteristic of fibroblasts were not counted. ${ }^{132}$ CD4:CD8 ratios were calculated for intraepithelial lymphocytes and lamina propria lymphocytes.

TABLE II Intraepithelial lymphocyte (IEL) counts (expressed as IEL/100 epithelial cells; values median (range))

\begin{tabular}{lcc}
\hline Group & No & IEL denisty \\
\hline Normal ileum & 12 & $12(9 \cdot 3-24 \cdot 8)$ \\
Normal colon & 12 & $6 \cdot 8(4 \cdot 7-9 \cdot 3)^{\star}$ \\
Pouches without pouchitis & 18 & $6 \cdot 9(5 \cdot 3-13)^{\star}$ \\
Pouchitis & 8 & $7 \cdot 3(4 \cdot 5-11 \cdot 6) \dagger$ \\
\hline
\end{tabular}

${ }^{\star} \mathrm{p}<0.001, \mathrm{tp}<0.002$ when compared with normal ileum. 
TABLE III TLymphocyte subpopulations (values given as median (range))

\begin{tabular}{lccc}
\hline $\begin{array}{l}\text { TCell } \\
\text { type }\end{array}$ & $\begin{array}{l}\text { Normal ileum } \\
(n=8)\end{array}$ & $\begin{array}{l}\text { Pouches without } \\
\text { pouchitis }(n=17)\end{array}$ & $\begin{array}{l}\text { Pouchitis } \\
(n=8)\end{array}$ \\
\hline Intraepithelial lymphocytes $(+$ ve IEL/100 epithelial cells): & \\
CD4+ & $3 \cdot 9(2-4 \cdot 7)$ & $1 \cdot 8(1-2 \cdot 6)^{\star}$ & $1 \cdot 7(1-2 \cdot 9)^{\star}$ \\
CD8+ & $12 \cdot 8(8 \cdot 5-17 \cdot 3)$ & $6 \cdot 1(3 \cdot 8-11 \cdot 4)^{\star}$ & $6 \cdot 7(5 \cdot 9-8 \cdot 3)^{\star}$ \\
CD4:CD8 & $0 \cdot 27(0 \cdot 15-0 \cdot 55)$ & $0 \cdot 32(0 \cdot 12-0 \cdot 53)$ & $0 \cdot 22(0 \cdot 17-0 \cdot 39)$ \\
Lamina propria lymphocytes $(\%+$ ve cells/total & mononuclear cells counted): & \\
CD4+ & $30 \cdot 1(17-38 \cdot 8)$ & $29(18 \cdot 8-38 \cdot 6)$ & $31(23 \cdot 8-42 \cdot 2)$ \\
CD8+ & $12 \cdot 3(8-16 \cdot 3)$ & $11 \cdot 9(7 \cdot 9-19 \cdot 3)$ & $13 \cdot 2(9 \cdot 2-19 \cdot 7)$ \\
CD4:CD8 & $2 \cdot 3(1 \cdot 9-3 \cdot 2)$ & $2 \cdot 4(1 \cdot 5-3 \cdot 9)$ & $2 \cdot 5(1 \cdot 8-3 \cdot 1)$ \\
\hline
\end{tabular}

${ }^{\star} \mathrm{p}<0.001$ compared with normal ileum.

\section{Macrophage subpopulations}

Positively stained macrophages as a percentage of the total number of mononuclear cells in the superficial lamina propria - for example in villi if preserved - were determined under the high power objective using a graticule. ${ }^{22}$ Three different areas of each section were counted, and for all sections the same area of superficial lamina propria was assessed. ${ }^{22}$ Again, cells in and around Peyer's patches and lymphoid follicles and mononuclear cells characteristic of fibroblasts were not counted. For sections stained with $3 \mathrm{G} 8$, positively staining neutrophils were not counted.

The sections were coded, and all counts were performed blindly by one investigator $(\mathrm{HJ}$ de $\mathrm{S})$, though most counts were confirmed independently by another $(\mathrm{MJ})$.

\section{STATISTICAL ANALYSIS}

Grouped data were expressed as median (range), and differences between measurements were assessed by the Mann-Whitney U test. Statistical significance was taken as $p<0 \cdot 05$.

\section{Results}

INTRAEPITHELIAL LYMPHOCYTE DENSITY COUNTS The clinical diagnosis of pouchitis was confirmed histologically in all eight patients. The results of the intraepithelial lymphocyte counts are shown in Table II. The intraepithelial lymphocyte densities in normal colon, pouches without pouchitis, and in pouches with pouchitis were significantly less than the densities found in normal ileum. There was no significant increase in intraepithelial lymphocytes, even in the presence of pouchitis, although numerous polymorphs were present in the surface epithelium in these sections. Intraepithelial lymphocyte densi-

TABLE IV Macrophage subpopulations (\% positive mononuclear cells/total mononuclear cells counted; values median (range))

\begin{tabular}{llll}
\hline $\begin{array}{l}\text { Monoclonal } \\
\text { antibody }\end{array}$ & $\begin{array}{l}\text { Normal ileum } \\
(n=8)(N I)\end{array}$ & $\begin{array}{l}\text { Pouches without pouchitis } \\
(n=17)(N P)\end{array}$ & $\begin{array}{l}\text { Pouchitis } \\
(n=8)(P)\end{array}$ \\
\hline Y2/131 & $23 \cdot 6(15-36 \cdot 1)$ & $23 \cdot 5(13 \cdot 6-36)$ & $26 \cdot 7(19 \cdot 1-32 \cdot 2)$ \\
EBM11 & $22 \cdot 9(15 \cdot 3-30 \cdot 3)$ & $23 \cdot 3(17-31 \cdot 7)$ & $26 \cdot 4(15 \cdot 7-38 \cdot 8)$ \\
RFD1 & $23 \cdot 5(17 \cdot 1-32 \cdot 1)$ & $23 \cdot 3(15-34 \cdot 3)$ & $27 \cdot 3(20-34 \cdot 7)$ \\
RFD7 & $17 \cdot 9(12 \cdot 9-25 \cdot 6)$ & $15 \cdot 9(11 \cdot 3-27 \cdot 9)$ & $19 \cdot 5(12-25 \cdot 8)$ \\
RFD9 & $0(0-2 \cdot 5)$ & $2(0-6 \cdot 5)$ & $9 \cdot 9(2 \cdot 6-15 \cdot 5)$ \\
3G8 & $0 \cdot 3(0-2 \cdot 5)$ & $0 \cdot 8(0-6 \cdot 8)$ & $8 \cdot 7(2 \cdot 8-16 \cdot 9)$ \\
Statistical significance: & $N I: N P$ & $N P: P$ & $N I: P$ \\
RFD9 & $\mathrm{p}<0 \cdot 02$ & $\mathrm{p}<0 \cdot 001$ & $\mathrm{p}<0 \cdot 001$ \\
3G8 & $\mathrm{p}=\mathrm{NS}$ & $\mathrm{p}<0 \cdot 001$ & $\mathrm{p}<0.001$ \\
Others & $\mathrm{p}=\mathrm{NS}$ & $\mathrm{p}=\mathrm{NS}$ & $\mathrm{p}=\mathrm{NS}$ \\
\hline
\end{tabular}

NS $=$ not significant. ties in pouches (with or without pouchitis) were similar to those found in normal colon. There was no significant correlation $\left(r_{s}=0.332\right.$, $p=0.097)$, between intraepithelial lymphocyte density and the degree of villous atrophy (villous height/total mucosal thickness) in pouches.

\section{T LYMPHOCYTE AND MACROPHAGE}

SUBPOPULATIONS

In control sections that were incubated with TBS instead of the primary antibody, no specific peroxidase staining was seen. Results of the cell counts of $\mathrm{T}$ lymphocyte subpopulations are shown in Table III. Most $\mathrm{T}$ cells in the epithelium were of the suppressor/cytotoxic phenotype $(\mathrm{CD} 8+) . \mathrm{CD} 4+$ (helper/inducer) cells predominated in the lamina propria. The absolute numbers of $\mathrm{CD} 4+$ and $\mathrm{CD} 8+$ intraepithelial lymphocyte/100 epithelial cells were significantly lower in pouches than in normal ileum $(\mathrm{p}<0.001)$. There was no significant increase in their numbers in the presence of pouchitis, and there were no significant differences in the epithelial CD4:CD8 ratios between normal ileum and pouches with or without pouchitis. Although there was an obvious increase in the cellular infiltrate within the lamina propria in pouches, especially in the presence of pouchitis, there were no significant differences in the lamina propria CD4:CD8 ratios between the three groups.

The results of the cell counts of macrophage subpopulations are shown in Table IV. There was a significant increase in the number of RFD9+ and 3G8+ cells in pouchitis compared with pouches without pouchitis and normal ileum. There was also a slight but statistically significant increase in RFD9+ cells, but not in $3 \mathrm{G} 8+$ cells, in pouches without pouchitis when compared with normal ileum. There were no significant differences between the three groups with regard to the other macrophage subtypes. In tissue sections from normal ileum and pouches without pouchitis, RFD1 + cells were found mainly in the superficial lamina propria (in villi, when preserved), while $\mathrm{Y} 2 / 131+$ and EBM $11+$ cells were seen throughout the lamina propria with a slight predominance in the superficial areas. RFD7+ cells were more evenly distributed throughout the depth of the mucosa. In pouchitis, these four cell types were evenly distributed throughout the mucosa. Of the eight specimens of normal ileum, there were no RFD9+ cells in five and no 3G8 + cells in four, and when present the numbers were small. In pouches without pouchitis $(n=17)$, there were no RFD9+ cells in four and no 3G8+ cells in eight. Both these cell types were present in all eight specimens with pouchitis. In pouchitis, both RFD9+ and 3G8+ cells were located mainly in the deeper parts of the lamina propria, and aggregates of RFD9+ cells were observed in two of the eight biopsy specimens. These aggregates were usually seen near the basal part of a crypt (Figure).

\section{Discussion}

There is clinical and pathological evidence that 


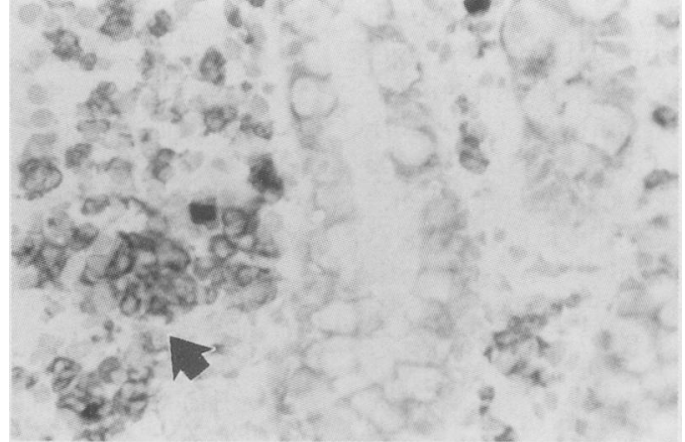

Sections from a pouch with pouchitis showing an aggregate of RFD9 positive cells (arrow)

the aetiology and pathogenesis of pouchitis are closely related to those of ulcerative colitis. ${ }^{4} 8^{10-12}$ In ulcerative colitis, recent interest has focused on events in the mucosal immune system (rather than changes in peripheral blood) and studies have been performed on mucosal T lymphocyte and macrophage subsets both on tissue sections and after cell isolation. ${ }^{13192122}$ The present study is the first to characterise $\mathrm{T}$ lymphocyte and macrophage subpopulations in the ileal pouch mucosa. Pouch intraepithelial lymphocytes have also been quantified, and the results compared with values obtained in normal small and large bowel.

The intraepithelial lymphocyte density in pouches was significantly less than that in normal ileum and similar to the density in normal colon. Furthermore, intraepithelial lymphocyte counts were persistently low, even in the presence of pouchitis. The finding of low counts in the colon confirms the results of other studies. ${ }^{13+}$ The reduction of intraepithelial lymphocytes in pouches may be the result of cells being lost into the intestinal lumen through the rapid epithelial cell turnover in pouches. ${ }^{45}$ These mechanical losses can occur in disease states where there is a high small intestinal epithelial cell turnover. ${ }^{46}$ In this study, however, there was no significant correlation between intraepithelial lymphocyte counts and the degree of villous atrophy (villous height/total mucosal thickness) which correlates strongly with crypt cell proliferation..$^{45}$ Although unproved, there is evidence that in the small intestine intraepithelial lymphocytes may reenter the lamina propria and leave the villi via lymphatics. ${ }^{3147}$ Thus, the reduction in intraepithelial lymphocytes in the pouch mucosa may partly be explained by their re-entry into the lamina propria. This re-entry may be related to the exposure of the pouch epithelium to a new luminal environment. The observation of low intraepithelial lymphocytes counts in ileal pouches is in agreement with the findings of Philipson et $a l^{48}$ and Shepherd et al, ${ }^{10}$ who reported that counts were always less than 5 intraepithelial lymphocytes/100 epithelial cells, even in the presence of pouchitis. Interestingly, there is a similar tendency for reduced counts in active inflammatory bowel disease, ${ }^{131+}$ but the importance of this is not known.

The intraepithelial lymphocytes that are found in intestinal epithelium are almost all T lymphocytes ${ }^{49}$ and show a striking predominance of CD8+ cells in health and disease, whereas the lamina propria contains mainly CD4+cells. ${ }^{13195051}$ This was also the case in the present study, .where CD8+ T cells predominated in the epithelium while CD4+ cells predominated in the lamina propria in both normal ileum and pouches. In ileal pouches, the numbers of both CD4+ and CD8+ intraepithelial lymphocytes/100 epithelial cells were lower than in normal ileum. There was, however, an increase in the cellular infiltrate within the lamina propria, especially in pouchitis. Despite this, the ratios of CD4:CD8 cells in the epithelium and lamina propria were not significantly different between normal ileum and pouches with and without pouchitis. This indicates that an imbalance of mucosal CD4+ and CD8 $+\mathrm{T}$ cells, as defined by monoclonal antibodies, is not responsible for the development of pouchitis. Similar conclusions have been drawn from the results of studies investigating mucosal CD4 and CD8 T cells in ulcerative colitis. ${ }^{13} 19$

The proportions of RFD9+ and 3G8+ macrophages were significantly higher in pouchitis than in normal ileum or pouches without pouchitis. RFD9 is a marker for epithelioid cells and tingible body macrophages. ${ }^{21} 3839$ In normal intestine RFD9+ cells are usually confined to lymphoid aggregates, the so called germinal centre or tingible body macrophages. ${ }^{21}$ Epithelioid cells in the granulomas of sarcoidosis $^{39}$ and Crohn's disease ${ }^{52}$ stain strongly with this antibody. Increased numbers of free lying RFD9+ macrophages have been found in the lamina propria in active ulcerative colitis and Crohn's disease (of the small and large bowel), but not in acute infectious colitis, ulcerative colitis in remission, or normal intestine..$^{21253}$

The monoclonal antibody $3 \mathrm{G} 8$ recognises the low affinity $\mathrm{Fc} \gamma$ receptor for monomeric IgG (Fc $\gamma$ receptor class III, CD16, 51-73 kD) found on polymorphs, natural killer cells, and some macrophages. ${ }^{10-43}$ It does not, however, recognise the low affinity $\mathrm{Fc} \gamma$ receptor, that is found on platelets and human monocyte lines. ${ }^{5+55}$ There is evidence that $\mathrm{Fc} \gamma$ receptor expression can be induced ${ }^{56}$ and that it may play a role in clearing immune complexes. ${ }^{57}$ This might be its function in inflamed intestine. Increased numbers of $3 \mathrm{G} 8+$ macrophages are present in active ulcerative colitis and Crohn's disease, and unlike RFD9+ macrophages they are also increased in acute infectious colitis. ${ }^{22}$

In pouches without pouchitis compared with normal ileum, the proportion of $3 \mathrm{G} 8+$ macrophages was not increased, but there was a slight but significant increase in the proportion of RFD9+ macrophages. This may reflect the continuing mild to moderate chronic inflammation seen in many functioning pouches in the absence of pouchitis. ${ }^{2910}$ A few RFD9+ macrophages were also found in the pouch biopsy specimens obtained from the three patients with familial adenomatous polyposis (as was the case in some specimens obtained from normal ileum). The small number of familial adenomatous polyposis patients that were available for this study precludes any comparisons with the specimens obtained from patients who had previously had ulcerative colitis.

There were no significant differences between 
normal ileum and pouches with and without pouchitis in the proportions of macrophages positive for the other monoclonal antibodies EBM11, Y2/131, RFD1, and RFD7. Both EBM 11 and Y2/131 detect CD68, a $110000 \mathrm{kDa}$ pan-human macrophage associated antigen. ${ }^{36}$ RFD1 detects an antigen on the HLA-D locus that is preferentially located on dendritic ('antigen presenting') cells and a small number of B lymphocytes, ${ }^{37} 3858$ while RFD7 recognises a 77 $\mathrm{kDa}$ antigen that is present on mature tissue macrophages. ${ }^{37}{ }^{38}$ Neither RFD1 or RFD7 is present on peripheral blood monocytes, and both are considered to be markers acquired during macrophage differentiation. ${ }^{37}$

This study has shown that there is a greater mucosal macrophage heterogeneity in patients with pouchitis than in those with normal ileum or pouches without pouchitis. This may reflect both a state of increased permeability to luminal antigens that may exist in pouchitis because of epithelial damage and phenotypic changes induced by mediators released during the inflammatory process. Since RFD9+ macrophages do not occur as a non-specific response to an acute infective process, their increased presence in pouchitis may suggest that mechanisms similar to those triggering the original ulcerative colitis are operating in pouchitis. This hypothesis is further supported by a recent observation that in pouchitis, as is the case in active ulcerative colitis, there seems to be a disproportionate increase in IgG containing plasma cells and not in IgA or IgM containing cells, ${ }^{5}$ although neither proper quantitation nor IgG subclass analysis have been performed.

H J de Silva was in receipt of an Overseas Research Student award and a Wingate Scholarship. We thank all those who supplied the monoclonal antibodies.

Parts of this work have been presented at meetings of the Medical Research Society, London, January 1990 (abstract: Clinical Science 1990; 78: 37), and the American Gastroenterological Association, San Antonio, Texas, May 1990 (abstract: Gastroenterology 1990; 98: A445)

1 Hulten L, Svaninger G. Facts about the continent ileostomy. Dis Colon Rectum 1984; 27: 553-7.

2 Moskowitz RL, Shepherd NA, Nicholls RJ. An assessment of inflammation in the reservoir after restorative proctocolectomy with ileoanal reservoir. Int $\mathcal{F}$ Colorectal Dis 1986; 1 : 167-74.

3 Kock NG. Continent ileostomy. In: Lee ECG, ed. Surgery of inflammatory bowel disorders. Edinburgh: Churchill Livingstone, 1987: 65-80.

4 Scott AD, Phillips RKS. Ileitis and pouchitis after colectomy for ulcerative colitis. Brf S urg 1989; 76: 668-9.

5 Meuwissen SGM, Hoitsma H, Boot H, Seldenrijk CA. Peuwissen SGM, Hoitsma H, Boot H, Seldenrijk
Pouchitis (pouch ileitis). Neth f Med 1989; 35: S54-66.

6 Hulten L. Workshop. Pouchitis. Int $\mathcal{F}$ Colorectal Dis 1989; 4: 205-29.

7 Tytgat GNJ. Workshop. Pouchitis. Int $\mathcal{F}$ Colorect Dis 1989; 4 : 205-29.

8 Madden MV, Farthing MJG, Nicholls RJ. Inflammation in ileal reservoirs: 'pouchitis'. Gut 1990; 31: 247-9.

9 O'Connell PR, Rankin DR, Weiland LH, Kelly KA. Enteric bacteriology, absorption, morphology and emptying after ileal pouch-anal anastomosis. Br 7 S urg 1986; 73: 909-14.

10 Shepherd NA, Jass JR, Duval I, Moskowitz RL, Nicholls RJ, Morson BC. Restorative proctocolectomy with ileal reservoir; pathological and histochemical study of mucosal biopsy specimens. $\mathcal{f}$ Clin Pathol 1987; 40: 601-7.

11 Tytgat GNJ, van Deventer SJH. Pouchitis. Int $\mathcal{F}$ Colorectal Dis 1988; 3: 226-8.

12 Shepherd NA. The pelvic ileal reservoir: apocalypse later? $B M \mathcal{F} 1990 ; 301: 886-7$.

13 Hirata I, Berrebi G, Austin LL, Keren DF, Dobbins WO Immunohistological characterization of intraepithelial and lamina propria lymphocytes in control ileum and colon and in inflammatory bowel disease. Dig Dis Sci 1986; 31: 593 603 .

14 Dobbins WO. Human intestinal intraepithelial lymphocytes. Gut 1986; 27: 972-85.

15 Lopes Pontes E. University of Oxford, 1982. (D Phil Thesis.)
16 Kobayashi K, Asakura H, Hamada Y, et al. T lymphocyte subpopulations and immunoglobulin-containing cells in the colonic mucosa of ulcerative colitis; a morphometric and immunohistochemical study. F Clin Lab Immunol 1988; 25: immus.

17 Scott MG, Nahm MH, Macke K, Nash GS, Bertovich MJ, MacDermott RP. Spontaneous secretion of IgG subclasses by intestinal mononuclear cells: differences between ulcerative colitis, Crohn's disease, and controls. Clin Exp Immunol 1986; 66: 209-15.

18 Kett K, Rognum TO, Brandtzaeg P. Mucosal subclass distribution of immunoglobulin $G$ producing cells is different in ulcerative colitis and Crohn's disease of the colon. Gastroenterology 1987; 93: 919-24.

19 Selby WS, Janossy G, Bofill M, Jewell DP. Intestinal lymphocyte subpopulations in inflammatory bowel disease: an analysis by immunohistological and cell isolation techniques. Gut 1984; 25: 32-40.

20 Selby WS, Poulter LW, Hobbs S, Jewell DP, Janossy G. Heterogeneity of HLA-DR-positive histiocytes in human intestinal lamina propria: a combined histochemical and immunohistological analysis. $\mathcal{f}$ Clin Pathol 1983; 36: 37984

21 Allison MC, Cornwall S, Poulter LW, Dhillon AP, Pounder RE. Macrophage heterogeneity in normal colonic mucosa and in inflammatory bowel disease. Gut 1988; 29: 1531-8.

22 Mahida YR, Patel S, Gionchetti P, Vaux D, Jewell DP. Macrophage subpopulations in the lamina propria of normal and inflamed colon and terminal ileum. Gut 1989; 30: 82634.

23 Mahida YR, Patel S, Wu K, Jewell DP. Interleukin 2 receptor expression by macrophages in inflammatory bowel disease. Clin Exp Immunol 1988; 74: 382-6.

24 Mahida YR, Wu KC, Jewell DP. Respiratory burst activity of intestinal macrophages in normal and inflammatory bowel disease. Gut 1989; 30: 1362-70.

25 Mahida YR, Wu K, Jewell DP. Enhanced production of interleukin $1-\beta$ by mononuclear cells isolated from mucosa with active ulcerative colitis or Crohn's disease. Gut 1989; 30: $835-8$.

26 Hermanowicz A, Gibson PR, Pallone F, Mason CH, Jewell DP. The function in vitro of macrophages from the intestinal mucosa of patients with Crohn's disease; and association between chemotactic migration and granulomata. tion between chemotactic migration

F Gastroenterol Hepatol 1988; 3: 117-25.
27 Mahida YR, Wu KC, Jewell DP. Characterization of antigenpresenting activity of intestinal mononuclear cells isolated presenting activity of intestinal mononuclear cells isolated
from normal and inflammatory bowel disease colon and from normal and inflammatory bowe

28 Wu KC, Mahida YR, Jewell DP. Effect of human macrophages on immunoglobulin production by human intestinal mononuclear cells isolated from patients with inflammatory bowel disease. Clin Exp Immunol 1990; 79: 35-40.

29 Ferguson A, Murray D. Quantitation of intraepithelial lymphocytes in human jejunum. Gut 1971; 12: 988-94.

30 Ferguson A, McClure JP, Townly RRW. Intraepithelial lymphocyte counts in small intestinal biopsies from children with diarrhoea. Acta Paediatr Scand 1976; 65: 541-6.

31 Ferguson A. Intraepithelial lymphocytes of the small intestine. Gut 1977; 18: 921-37.

32 Ross IN. Mathan VI. Immunological changes in tropical sprue. QF Med 1981; 50: 435-49.

33 Scott BB, Losowsky MS. Patchiness and duodenal-jejunal variation of the mucosal abnormality in coeliac disease and dermatitis herpetiformis. Gut 1976; 17: 984-92.

34 Corazza GR, Frazzoni M, Dixon MF, Gasbarrini G. Quantitative assessment of the mucosal architecture of jejunal specimens: a comparison between linear measurement, stereology and computer aided microscopy. $\mathcal{F}$ Clin Pathol 1985; 38: 765-70.

35 Nasmyth DG, Godwin PGR, Dixon MF, Williams NS, Johnston D. Ileal ecology after pouch-anal anastomosis or ileostomy: a study of mucosal morphology, fecal or ileostomy: a study of mucosal morphology, fecal bacteriology, fecal volatile fatty acids, and
relationship. Gastroenterology 1989; 96: 817-24.

36 Micklem K, Rigney E, Cordell J, et al. A human macrophageassociated antigen (CD68) detected by six different monoassociated antigen (CD68) detected by six differ

37 Poulter LW, Campbell DA, Munro C, Janossy G. Discrimination of human macrophages and dendritic cells by means of monoclonal antibodies. Scand F Immunol 1986; 24: 351-7.

38 Janossy G, Bofill M, Poulter LW. Two colour immunofluorescence analysis of the lymphoid system with monoclonal antibodies in histology. In: Van Noorden S, Polak J, eds. antibodies in histology. In: Van Noorden S, Polak J, eds.

39 Munro CS, Campbell DA, Collings LA, Poulter LW. Monoclonal antibodies distinguish macrophages and epithelioid
cells in sarcoidosis and leprosy. Clin Exp Immunol cells in sarcoid

40 Fleit HB, Wright SD, Unkeless JC. Human neutrophil Fc receptor distribution and structure. Proc Natl Acad Sci 1982; 79: 3275-9.

41 Perussia B, Trinchieri G. Antibody 3G8, specific for human neutrophil Fcg receptor reacts with natural killer cells. f Immunol 1984; 132: 1410-5.

42 Anderson CL, Looney RJ. Human leucocyte IgG Fc receptors. Immunol Today 1986; 7: 264-9.

43 Unkeless JC, Scigliano E, Freedman VH. Structure and function of human and murine receptors for IgG. Annu Rev function of human and $1988 ; 6: 251-7$.

44 Bedossa P, Poynard T, Bacci J, et al. Expression of histocompatibility antigens and characterization of the lymphocyte infiltrate in hyperplastic polyps of the large intestine. Hum Pathol 1990; 21: 319-24. 
45 de Silva HJ, Gatter KC, Millard PR, Kettlewell M, Mortensen NJ, Jewell DP. Crypt cell proliferation and HLA-DR expression in pelvic ileal pouches. $\mathcal{f}$ Clin Pathol 1990; 43 . 824-8.

46 Marsh MN. Functional and structural aspects of the epithelial lymphocyte, with implications for coeliac disease and lymphocyte, with implications for coeliac disease and
tropical sprue. Scand f Gastroenterol 1985; 20 (suppl): 55 trop.

47 Marsh MN. Studies of intestinal lymphoid tissue 2 . Aspects of proliferation and migration of epithelial lymphocytes in the small intestine of mice. Gut 1975; 16: 674-82.

48 Philipson B, Brandberg A, Jagenburg R, Kock NG, Lager I Ahren C. Mucosal morphology, bacteriology, and absorption in intra-abdominal ileostomy reservoir. Scand $\mathscr{f}$ Gastroenterol 1975; 10: 145-53.

49 Selby WS, Janossy G, Jewell DP. Immunohistological characterisation of intraepithelial lymphocytes of the human gastrointestinal tract. Gut 1981; 22: 169-76.

50 Selby WS, Janossy G, Goldstein G, Jewell DP. T lymphocyte subsets in human intestinal mucosa: the distribution and relationship to MHC-derived antigens. Clin Exp Immunol relationship to

51 Selby WS, Janossy G, Bofill M, Jewell DP. Lymphocyte subpopulations in the human small intestine. The findings in normal mucosa and in the mucosa of patients with adult coeliac disease. Clin Exp Immunol 1983; 52: 219-28.

52 Mahida YR, Patel S, Jewell DP. Macrophage and lymphocyte subpopulations in the granuloma of Crohn's disease. In: MacDermott RP, ed. Inflammatory bowel disease: curren status and future

53 Gionchetti P, Mahida YR, Patel S, Jewell DP. Macrophage and lymphocvte subpopulations in magnifying endoscopic and lymphocyte subpopulations in magnifying endoscopic lesion

54 Rosenfield SI, Looney RJ, Leddy DC, Phillips DC, Abraham $\mathrm{GN}$, Anderson CL. Human platelet $\mathrm{Fc}$ receptor for immunoglobulin G. $\mathcal{F}$ Clin Invest 1985; 76: 2317-22

55 Jones DH, Looney RJ, Anderson CL. Two distinct classes of IgG Fc receptors on a human monocyte line (U937) defined by differences in binding of murine IgG subclasses at low in ionic strength. F Immunol 1985; 135: 3348-53.

56 Unkeless JC, Springer TA. Application of monoclonal antibodies: macrophages. In: Weir DM, Herzenberg LA, Blackwell C, eds. Handbook of experimental immunology 4. Applications of immunological methods in biomedical sciences. Oxplications of immunological methods in biomedic

57 Clarkson SB, Kimberley RP, Valinsky JE, et al. Blockade of clearance of immune complexes by an anti-Fig receptor
con monoclonal antibody $\mathcal{F}$ Exp Med 1986;164: $47+89$.

58 Mahida YR, Patel S, Jewell DP. Mononuclear phagocyte system of human Peyer's patches: an immunohistochemical study using monoclonal antibodies. Clin Exp Immunol 1989 75: $82-6$. 